\title{
Cranberry Fruit Rot in the Northeast: A Complex Disease
}

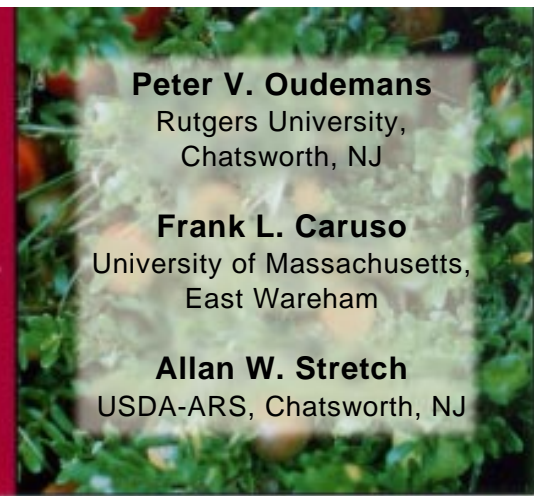

$T$ he large American cranberry (Vaccinium macrocarpon Aiton) is one of a handful of native North American plant species grown as a commercially viable agricultural crop. Other examples include muscadine grapes, pecans, sunflowers, and blueberries. Cranberries belong to the plant family Ericaceae, along with blueberry, azalea, various laurels, huckleberry, lingonberry, and numerous others (60). The plant is a long-lived perennial that can be propagated either vegetatively or by seed. It grows as vines that form a dense carpet of runners (i.e., long primary stems growing along the surface), each supporting many reproductive uprights (i.e., flowering shoots growing vertically) (Fig. 1). Flowering occurs from early June to early July, depending on the geographic location, and fruit begin to ripen by late September but can be harvested until low temperatures cause the fruit to freeze.

Cranberries were originally harvested from natural stands in Cape Cod, Massachusetts, by native Americans. The plant was introduced to the early settlers, who valued the fruit for both nutritional and medicinal properties. It was well-known in the seventeenth and eighteenth centuries that ingestion of cranberries could prevent a variety of ailments, including scurvy (31). Cranberries were even recommended as an additive to feed for improving the health of farm animals. Physicians sometimes used cranberries in a poultice to prevent infections from developing in open wounds. The berries were known to contain food preservatives which, when pounded into meats, decreased spoilage in the absence of refrigeration (31). Today,

Dr. Oudemans' address is: Rutgers University, Blueberry and Cranberry Research and Extension Center, Chatsworth, $\mathrm{NJ}$;

E-mail: oudemans@aesop.rutgers.edu

Publication no. D-1998-0909-01F

(C) 1998 The American Phytopathological Society the reputed health benefits of the cranberry have survived the scrutiny of the scientific method. In a double-blind study, it was demonstrated that consumption of cranberry juice is active in preventing bladder infections in elderly humans (2).

\section{Cranberry Production}

Cranberry cultivation was initiated in the early nineteenth century to satisfy an increasing demand for the fruit in both North America and Europe. Early entrepreneurs in Massachusetts and New Jersey developed many of the methods still used in cranberry cultivation today $(28,43,66)$. Cranberries are grown in well-engineered beds, usually constructed on either peat or sand, and are positioned within 0.3 to 0.8 $\mathrm{m}$ of the water table. They are surrounded by dikes and ditches that are connected to a system of underground drainage tiles or surface ditches that form networks to regulate water flow into and away from the beds (Fig. 2). The beds are sometimes covered with a layer of washed sand prior to planting to provide rapid drainage during the growing season. The crop is planted either by "pressing in" hardwood cuttings obtained from pruning vines in mature beds or by using rooted cuttings. A profitable yield is usually attained within 3 to 5 years of planting, and a bed will reach its maximum productivity sometime after that. Established beds are usually not renovated unless productivity drops or weed infestations become too severe. In a sense, a well-managed cranberry bed is nearly immortal. In New Jersey and Massachusetts, some beds have been in production for over 100 years.

The productivity of the crop is maximized through management practices such as optimized nutritional regimes, application of new sand layers every 3 to 8 years,

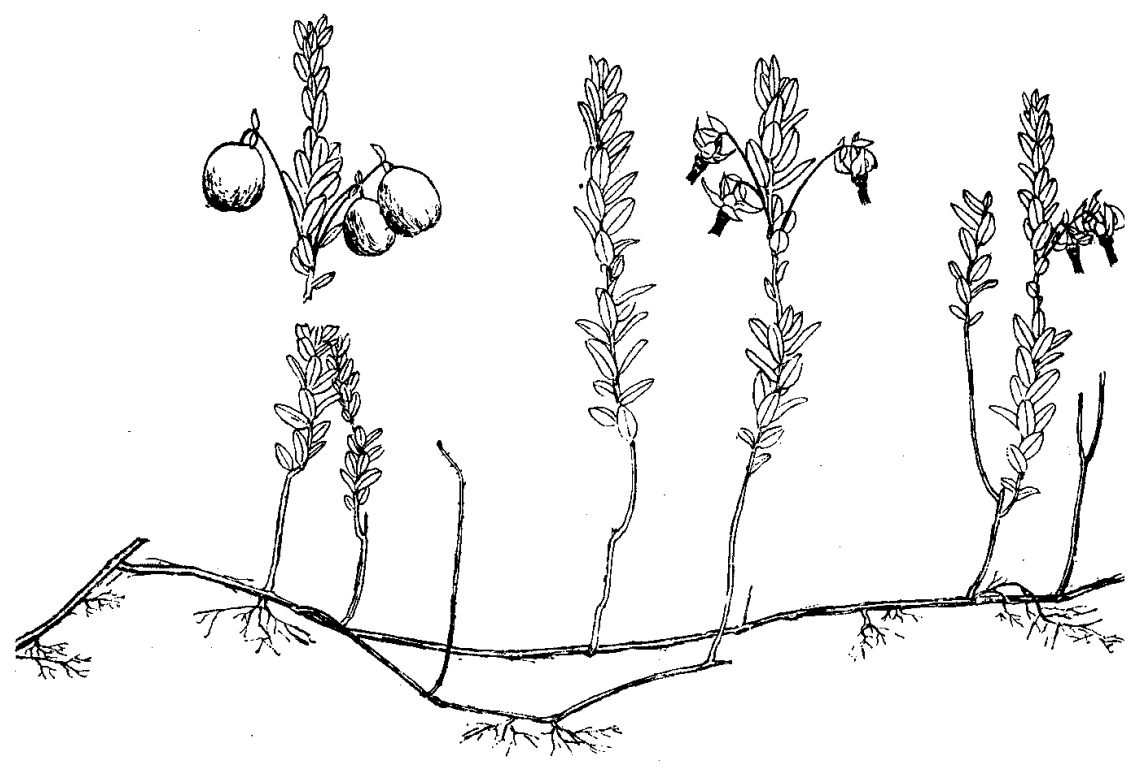

Fig. 1. Drawing of the large American cranberry (Vaccinium macropcarpon) showing a runner with roots and an upright bearing flowers and fruits. From Beckwith (6). 
frost protection using overhead irrigation, and use of integrated crop management (ICM) (27). Yield in cranberry is based on several components, including the density of flowering uprights, the number of flowers per flowering upright, the proportion of fruit set, and berry size. Two components, the density of flowering uprights and the proportion of fruit set, appear to have the greatest impacts on yield $(29,30)$. Yields ranging from 14,000 to $28,000 \mathrm{~kg} / \mathrm{ha}$ are typical, but yields in excess of 56,000 $\mathrm{kg} /$ ha have been recorded (Ocean Spray Cranberries, Inc., Lakeville-Middleboro, MA, personal communication). However, within a single cranberry bed, yields can vary 10 - to 100 -fold (P. V. Oudemans, personal observation).

Large volumes of water are crucial to successful cranberry production. In the East and Midwest, where winters are cold, the beds are flooded to a depth of 0.25 to $1.0 \mathrm{~m}$ during the winter months to prevent cold temperature damage and desiccation. In Massachusetts, floodwaters are sometimes removed during the winter to avoid the deleterious effects of anoxia caused by low dissolved oxygen concentrations in the water (7). Once the winter floodwater is permanently removed, the growing season begins. Prior to widespread use of overhead irrigation for frost protection, the winter floodwater was typically removed in late May, but it is now removed as early as late March. Overhead irrigation systems cover at least $95 \%$ of the current commercial acreage and most commonly draw from surface-fed reservoirs (Fig. 3). The crop is generally irrigated during the summer months with approximately $3 \mathrm{~cm}$ of water per week (37). It is a common misconception that cranberries are grown under wet, boggy conditions. In fact, during the summer months, the beds tend to be dry. Water again plays a significant role during the harvest (Fig. 4). The beds are flooded, and the fruit is dislodged from the vines by specialized machinery (25). The buoyant berries are corralled in floating booms, similar to the ones used to contain oil spills in the ocean, and lifted by conveyor or pump into containers. Dry harvesting is an alternative method that is used primarily for fruit destined for the fresh market.

Harvested fruit is used in one of two ways: either for processing into juice, sauce, and a variety of other products, or marketed directly as fresh fruit. Fruit harvested for fresh-market sale is generally cleaned, air-dried, and stored for several weeks until it can be marketed for the appropriate holiday season. Fresh fruit sales usually account for less than $10 \%$ of the total North American crop sales (43). For fresh fruit, "keeping quality," which is partly a function of the amount of fungal infection, represents the shelf life of stored berries. For processing fruit, keeping quality usually is not a major issue because the fruit is frozen soon after harvest.

Due to the specific environmental requirements of the cranberry plant, production is limited to only a few states. The major production areas include Massachusetts, Wisconsin, New Jersey, British Colombia, Washington, and Oregon (42). Limited production and new industry opportunities exist elsewhere, such as Chile, Quebec, Michigan, Nova Scotia, New Brunswick, and Ontario. In Europe, the industry is less well developed. This may be due to a lack of plant material and cultivation of the related species, $V$. vitis-idaea. One exception is the island of Terschelling in the Netherlands, which hosts an annual cranberry harvest. Those cranberries are

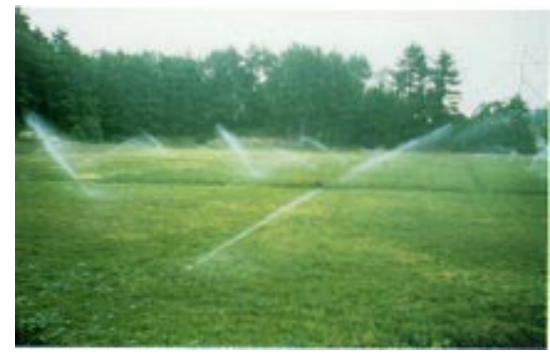

Fig. 3. Overhead irrigation of a cranberry bed to prevent water stress, heat stress, and frost damage.
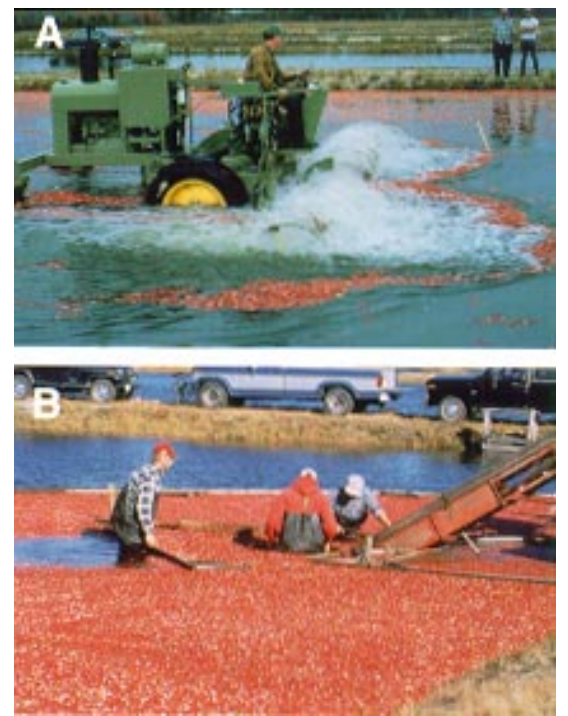

Fig. 4. Cranberry harvest. (A) A water reel harvester knocks ripe fruit from the vines. (B) Fruit is corralled with floating booms and is then lifted via conveyor into trucks.
Fig. 2. An infrared aerial photograph of cranberry beds in New Jersey taken in Jun 1993. Cranberry beds are separated by a network of dikes and ditches. They require an abundant water supply, which is used for irrigation during the growing season, flooding for harvest, and protection from winter damage. 
believed to have originated from a shipwreck that occurred during the eighteenth or nineteenth century.

\section{Cranberry Fruit Rot: The Early Days}

Soon after establishment of the first cranberry beds in New Jersey, a severe fruit disease was eliminating most of the crop (35). The growers of that era found that a bed could produce healthy fruit for as long as 5 to 10 years before succumbing to "the rot" (Fig. 5) (36). Theories about the cause of the rot were numerous. In the 1880 s, fungi were not immediately implicated, but insect damage was recognized as a problem distinct from that of fruit rot. The actual cause of fruit rot remained unknown for several years. Many treatments were tried, but none were consistently effective. Theodore H. Budd, an early cranberry grower and one-time president of the American Cranberry Growers Association from New Jersey, summarized the situation in 1883 as follows (taken from the Official Proceedings of the 11th Annual ACGA Convention):

There was a time, and only a few years ago, when this subject (rot) was the leading feature of the Association, when the members dared not to speak or listen to any other subject; and, in fact, I do not think this Association would have an existence today if this curse or blessing, whichever it may be, had not come upon us. Then we required large public halls in which to hold our meetings, and the large attendance was fully equaled by the interest and zeal manifested by its members, and our meetings were too short and few in number for the members thirsty after knowledge.
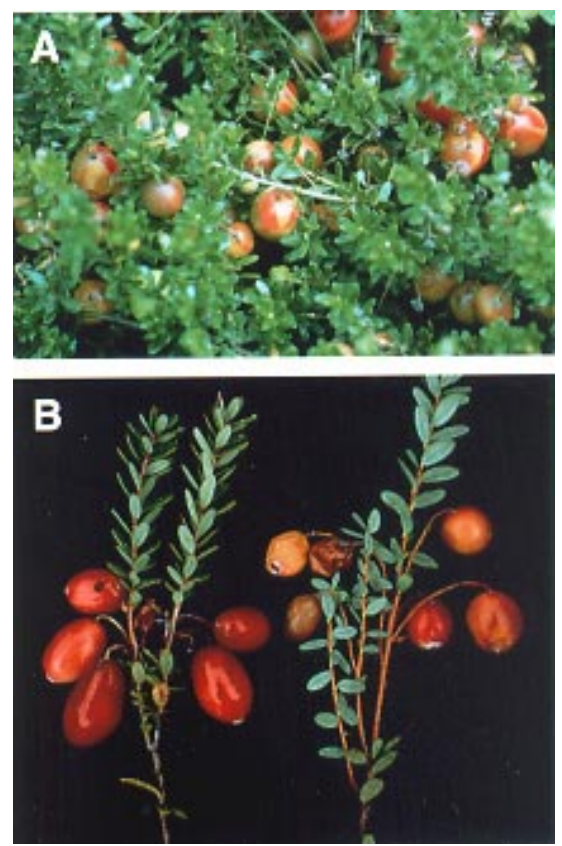

Fig. 5. Cranberry fruit rot. (A) Symptoms of a severe case of cranberry fruit rot in the field. (B) Symptoms of cranberry fruit rot showing healthy fruit on the left and diseased fruit on the right.
Liberal sums of money were readily contributed to obtain the best scientists in the country, and our distress was so great, and our petitions so loud, that the Government came to our rescue and our meetings were honored for several years by the presence of Professor Taylor sent here by the Commissioner of Agriculture as a scientist and expert, to lead us out of our troubles and place the cranberry growers of New Jersey once more on the road to prosperity.

At the meeting of his first attendance he explained to us the cause and prescribed the remedy and many a sad grower went home with a light heart and rosy expectations of hereafter gathering sound berries from his bogs that now produced only rotten ones.

Prof. Taylor found our bogs too sour, and needed lime or some other fertilizer to neutralize the poison acids and sweeten them; and in examining the many bogs he visited, he only found one perfect bog - only one bog that needed no medicine and would be likely to always grow sound fruit. This was Mr. Bishop's bog, at Manahawkin. But this perfect bog soon became sick, indeed so sick that medicine did it no good, and, like many other bogs went from bad to worse.

Halsted (36) was the first to associate fungi as a causative agent with cranberry fruit rot. In a detailed survey of commercial growers in the Northeast, Halsted reported that preharvest fruit rot was most severe on New Jersey farms but was also locally severe elsewhere. The postharvest fruit rot was, however, common to all growing regions surveyed at that time. The fungus (Halsted's illustrations suggest more than one species.) was found on all parts of the cranberry plant. During the period from 1900 to 1950 , the USDA and state mycologists and plant pathologists from the northeastern region, such as $\mathrm{C}$. L. Shear, H. J. Franklin, M. S. Wilcox, N. E. Stevens, R. B. Wilcox, and H. F. Bergman, as well as H. F. Bain from the Central and Pacific regions, conducted the true pioneering research on this and other destructive diseases of cultivated cranberries (48).

\section{Causes of Cranberry Fruit Rot}

Cranberry fruit rot is a generic term applied to any rot symptom affecting the berries. In practice, there are two types recognized, field rot and storage rot (Fig. 6). Ten to 15 species of fungi have been implicated in both forms of the disease $(3,9-14,39,46,48)$, and there is considerable overlap among the causal agents (Fig. 6). For example, Physalospora vaccinii can be both an important field- and storagerotting species. On the other hand, Colletotrichum gloeosporioides and Allanto-

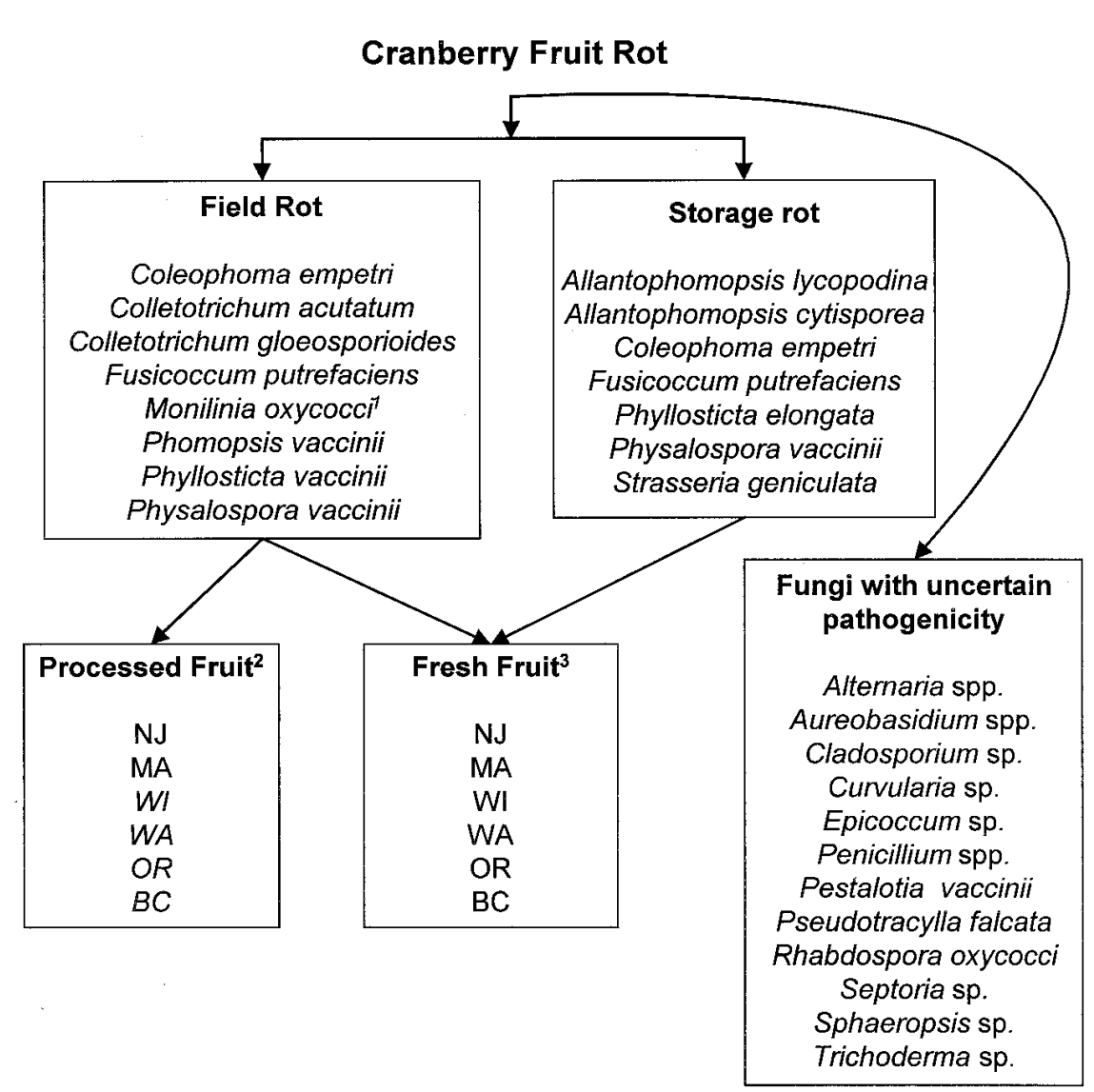

Fig. 6. Causes of cranberry fruit rot. Fungi listed under the field and storage rot categories are confirmed fruit rot pathogens capable of causing significant economic damage. The remaining fungi may be infrequent pathogens or nonpathogenic, and are for the most part untested. States in italics under processed fruit have very mild fruit rot pressure and do not generally spray for this disease. New Jersey does not produce large volumes of fresh fruit because the keeping quality is generally poor. 
phomopsis spp. appear to be more specific to the field or storage rots, respectively (44,55). In addition, major differences exist in the frequencies of the pathogen species among the various cranberry growing areas. Field rot tends to be most severe in New Jersey and Massachusetts, while the disease pressure is much lower in Wisconsin and the western growing areas such as Oregon, Washington, and British Colombia (31).

It can be very difficult to identify the causal organism by rot symptom alone, because symptoms caused by individual fungi are usually not distinct. Fungi from diseased tissue must be cultured soon after symptoms appear to ensure that the specific pathogens causing disease are isolated (Fig. 7). Symptoms of fruit rot in the field begin to appear in early July, and the incidence increases throughout the season. The relative importance of field rot compared with storage rot depends largely on the end use of the crop. In the East, fruit destined for processing is frozen soon after harvest, and thus storage rot is of minor importance. Fruit used in the fresh market is harvested and then stored under refrigeration for as long as 3 months until sold, and storage rots can be vitally important. The fungi responsible for these diseases represent a diverse group of Ascomycetes and Fungi Imperfecti (Fig. 6) whose taxonomy is relatively well described $(17,33,48,63)$. Although Koch's postulates have been conducted on relatively few of these fungi, the species believed to be most important
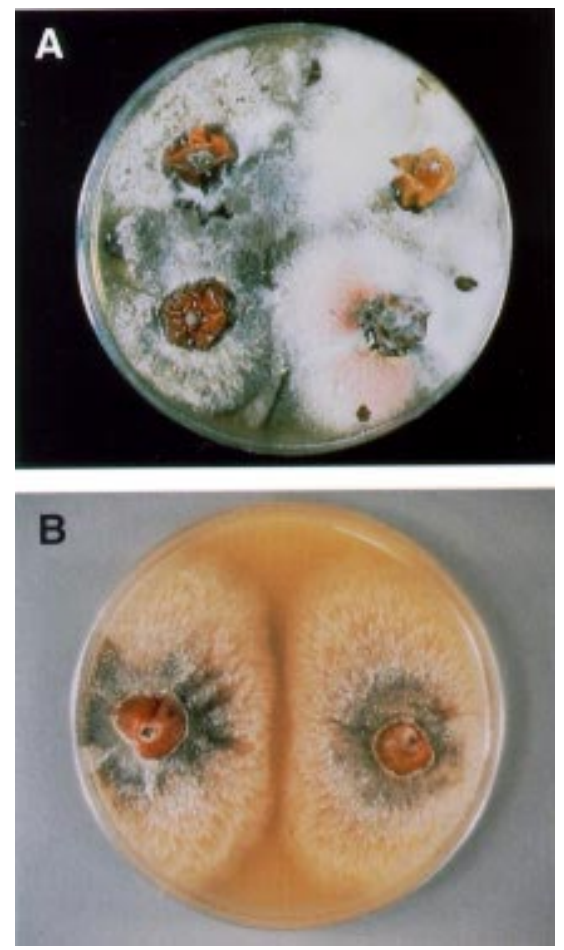

Fig. 7. Examples of fruit cultured on V8 juice agar after surface sterilization. (A) Colletotrichum gloeosporioides (left) and C. acutatum (right), and (B) Physalospora vaccinii. in fruit rot on commercial cranberry farms today have had pathogenicity confirmed (9,11-14,16,45,54,64,65). However, some important exceptions do exist. For example, Phomopsis vaccinii is commonly isolated from both diseased uprights and rotted fruit, but artificial inoculations have not been successful. A unique cause of cranberry fruit decay that resembles fruit rot is referred to as "sterile breakdown," and no biotic agents have been implicated in this disorder (22).

Several surveys have been conducted to determine the cause of cranberry fruit rot, and numerous fungal species are found associated with both sound and rotted fruit (Fig. 6). It has not been fully determined which of the less common species are primary pathogens and which are secondary colonizers. Surveys conducted in New Jersey from 1926 to 1929 indicated that Phyllosticta vaccinii and sterile breakdown were the most common causes of fruit decay occurring around harvest time. Similarly, Weidemann and Boone (64) found Phyllosticta vaccinii to be a very prevalent species in New Jersey field-rotted fruit from 1975 to 1978. More recently, C. M. Stiles and P. V. Oudemans (unpublished) conducted a survey in New Jersey and found two species, Physalospora vaccinii and Colletotrichum gloeosporioides, to be the most commonly isolated fungi from decayed fruit from 1994 to 1995; in 1996, the frequency of $C$. gloeosporioides had declined markedly. Other species, such as Coleophoma empetri, Phyllosticta vaccinii, and Phomopsis vaccinii, were isolated at high frequencies from a limited number of locations. In Massachusetts, Godronia cassandrae (anamorph Fusicoccum putrefaciens), Colletotrichum gloeosporioides, Coleophoma empetri, Phyllosticta vaccinii, and sterile breakdown were the most common causes of fruit decay from 1926 to $1933(8,48)$. Zuckerman (68) reported and Caruso (12) has since verified an increase in the prevalence of Coleophoma empetri compared with the earlier surveys in Massachusetts. Numerous other fungi are commonly isolated from cranberry leaves and fruit (38; C. M. Stiles and P. V. Oudemans, unpublished), but many of these species have uncertain pathogenicity. The causes of change in frequency and importance of fruit-rotting species over time are not known; however, these changes do indicate that fungi currently considered unimportant could emerge as major factors affecting fruit quality in the future.

One remarkable feature of cranberry fruit rot is the lack of evidence for bacterial-related decays. Although bacteria are frequently isolated from leaf and fruit surfaces (4), there are few, if any, published accounts that implicate bacteria as cranberry pathogens. In fact, relatively few bacterial diseases have been reported from any Ericaceous plant (22). Kobayashi et al. (41) reported a new blueberry leaf spot caused by Pseudomonas andropogonis, but tests with this bacteria indicated it was only weakly pathogenic to cranberry.

\section{Life Cycles}

Cranberry fruit-rotting fungi appear to exist as indigenous populations in cranberry beds. As such, each species must overwinter within the bed. In commercial cranberry culture, the role of infected fruit as a source of inoculum is uncertain, but it is probably insignificant since the majority of fruit is removed from the beds prior to the formation of any type of fruiting structure. Furthermore, experiments testing

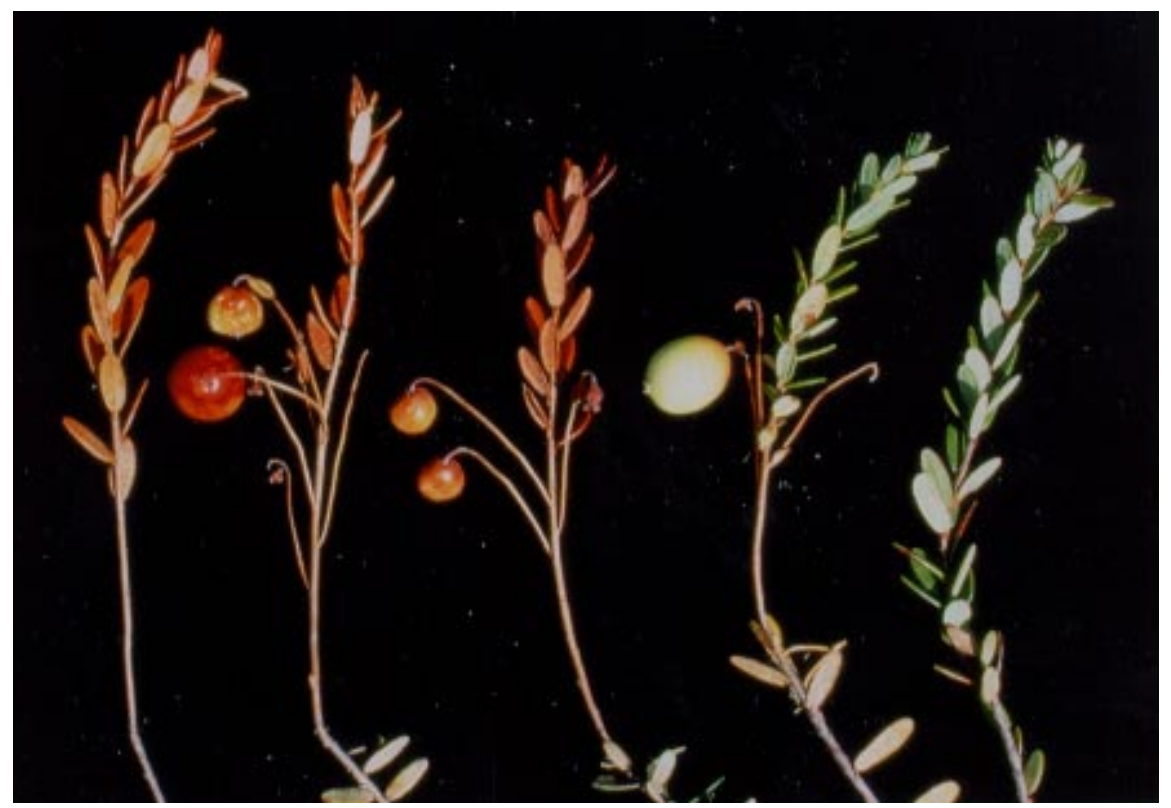

Fig. 8. Upright dieback caused by Phomopsis vaccinii. This fungus also has a fruit rotting phase. Fruit in this photo are shriveled from dehydration due to vine death. 
the transmissibility of fruit rot in storage indicate that there is virtually no spread from infected to healthy fruit (34).

Of the fruit-rotting species that have been studied, there appear to be three general types of life cycles that differ with respect to the tissues where the fungi overwinter and the timing of fruit infection. These distinctions are made for the first time in this article and are useful because they illustrate some basic differences in the life histories of these fungi. These different life cycle types may be modified as research reveals more details of the fungal life histories, but at this stage, the classifications serve to distinguish 12 fungal species into three general groups.

Life cycle type I. These fungi overwinter in older tissues such as woody stems or persistent pedicels. Spore-bearing structures probably form on these woody tissues when the growing season begins. Infections leading to fruit rot begin during bloom and early fruit set, but the duration of spore dissemination is unknown. Species with this type of life cycle include Colletotrichum gloeosporioides (55), Fusicoccum putrefaciens (47), Phomopsis vaccinii (33), and possibly Synchrono-

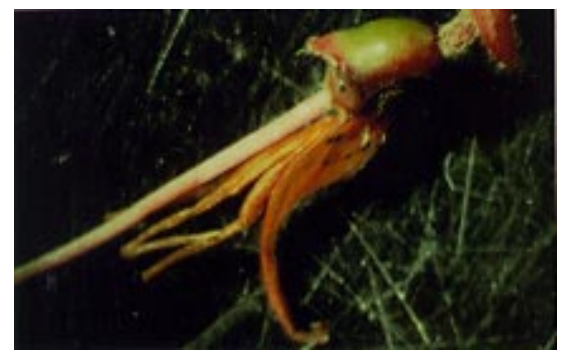

Fig. 9. Blossom blast caused by Phyllosfruit rot and leaf drop. ticta vaccinii. This fungus also causes

blastia crypta (59). Of the species mentioned in this category, Phomopsis vaccinii and Synchronoblastia crypta also cause a vine disease known as upright dieback (Fig. 8). Infections by these species are presumed to occur during vegetative bud break, although infection studies have been unsuccessful and Koch's postulates have not been confirmed.

Life cycle type II. These fungi survive in living leaves as latent infections or possibly as endophytes. In cranberry, leaves generally remain on the vines for 2 years. Sporulation occurs as leaves begin to senesce, usually in the summer 2 years after they were formed, but there are some exceptions. Infections leading to fruit rot probably begin during late bloom, but again, the duration of spore dissemination is unknown. The species reported in this category include Coleophoma empetri (48), Phyllosticta elongata (55,65), Phyllosticta vaccinii (64), and Physalospora vaccinii (55). One species, Phyllosticta vaccinii, can also be a leaf or flower blossom pathogen (Fig. 9). The remaining species appear to have little effect on the host plant, and symptoms appear after the leaves begin to senesce or as the fruit ripens.

Life cycle type III. These fungi also overwinter in living and dead leaves and stems (22); however, the majority of fruit infection occurs during harvest. When the beds are flooded, large numbers of spores can be found in the floodwater (45), and these spores can cause infections at wound sites inflicted on the fruit during harvest $(45,57)$. Infections may also occur in dryharvested fruit, but at very low frequencies. Species with this type of life cycle include Strasseria geniculata, Allantophomopsis cytisporea, and Allantophomopsis lycopodina. Black rot is a specific type of

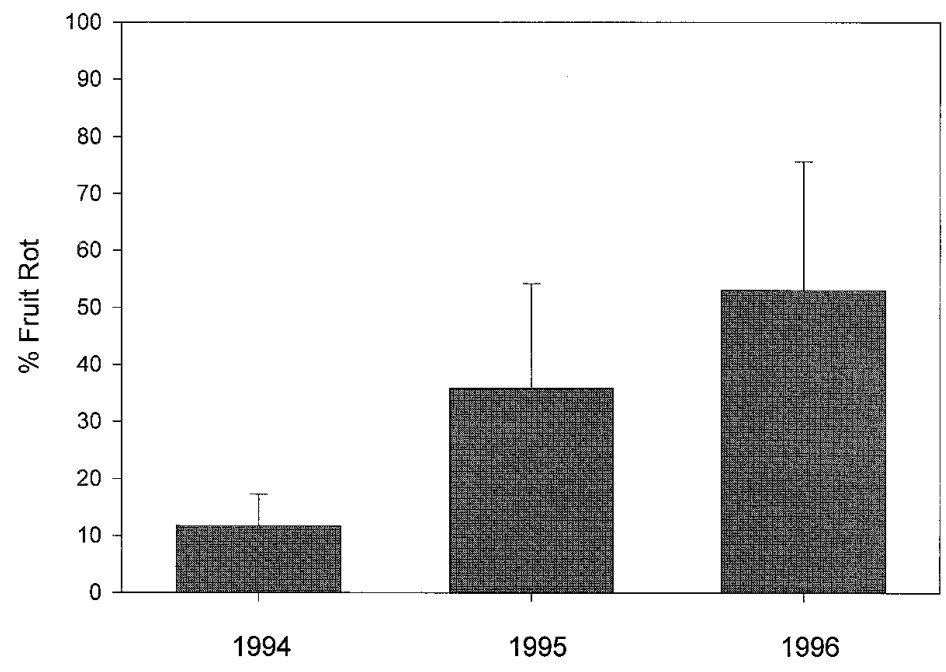

Fig. 10. Increase in cranberry fruit rot in the absence of fungicides. These data were collected from experiments conducted on a 0.2-ha (0.5-acre) experimental cranberry bed at the Rutgers University Blueberry and Cranberry Research and Extension Center over a 3-year period. Fruit rot levels in fungicide-treated beds ranged between 2 and $10 \%$ (P. V. Oudemans, unpublished data). fruit rot with distinct symptoms commonly caused by these fungi.

Cranberry fruit rot, in general, seems to behave as a simple-interest disease (sensu Vanderplank [61]). Disease increase from year to year usually occurs in a step-wise fashion in the absence of controls (Fig. 10). However, there is very limited information on the frequency of infection cycles, the duration of latent periods, and timing of sporulation. We believe that most of the species mentioned above, with the exception of Phyllosticta vaccinii, complete a single infection cycle once every 1 to 3 years. Zuckerman (68) hypothesized that infections occur through the receptive stigma. Although this has been substantiated for the cottonball pathogen, Monilinia oxycocci, it does not appear to be true for the other fruit-rotting species (5). Much of the evidence on the timing of infection comes from experiments investigating the effect of timing of fungicide applications. P. V. Oudemans and F. L. Caruso (personal observations) demonstrated under both New Jersey and Massachusetts conditions that protection of the developing fruit during late bloom and early fruit set is critical for effective disease control. Applications made following the bloom period are progressively less effective as time increases (Fig. 11). Chemical control of the storage rots, especially the type III species, has been less successful, probably because of the lateness of infection.

\section{Keeping Quality}

Keeping quality is essentially a measure of the shelf life of refrigerated fruit. Stevens (49) defined keeping quality as the proportion of spoilage that develops in storage after a predefined period. The keeping quality is to a large degree related to the amount of fungal infection of the fruit; however, in some years, significant losses due to sterile breakdown (fruit softening without evidence of culturable fungi) occur. Historically, keeping quality was determined by the shipper, who had to sort fruit after storage and before sending it to market. Stevens (51-53) found that keeping quality varied tremendously from one year to the next, as well as among varieties. He initiated research aimed at predicting the keeping quality of cranberry fruit each season (50). Using weather data and detailed records of keeping quality taken by cranberry shippers, he developed a data set dating back to the year 1912 to be used to identify weather factors that influence keeping quality. When this work began, keeping quality predictions were vitally important for growers needing to make the best management and marketing decisions. The major components of Stevens' forecast included monthly rainfall totals and average temperatures for the early part of the growing season (March to April) and again for the latter part of the 
season (August to September). The forecasts generally predicted superior keeping quality when spring temperatures were low. However, the predictions were not always accurate. One storage-rotting species, Fusicoccum putrefaciens, which grows well at low temperatures $(47,48)$, did cause significant losses in some seasons predicted to have excellent keeping quality. Franklin and Cross (32) made several improvements to Stevens' predictive scheme (Table 1). Specifically, the hours of sunlight from the previous year, as well as sunlight hours during the months of February and March, were added, and the August-September components were eliminated. Their scheme also provided weighting values for each component (Table 1). Predictions for keeping quality, based on the method of Franklin and Cross (32), have been issued by the University of Massachusetts Cranberry Experiment Station since 1949. The predictions are generally on the conservative side and therefore are considered especially useful by growers of fresh fruit.

\section{Economic Importance of Cranberry Fruit Rot}

Cranberries are a high-value crop. Typical production in the range of 14,000 to $28,000 \mathrm{~kg} / \mathrm{ha}$ can translate to $\$ 18,500$ to $\$ 73,000$ per ha of gross income based on 1997 values. Prior to utilization of fungicides, cranberry fruit rot was responsible for up to $100 \%$ crop loss in worst-case scenarios and routinely reduced the New Jersey crop by $33 \%$ (36). With the development of Bordeaux mixture, cranberry fruit rot could be reduced by as much as 10 to $50 \%$ (67). Development of more effective fungicides, including carbamates (ziram and ferbam), ethylene bisdithiocarbamates (maneb, zineb, and mancozeb), captafol, and chlorothalonil, permitted further reductions in the incidence of fruit rot $(62,67)$. Through improved crop management practices and correct timing of fungicide applications, cranberry fruit rot in Massachusetts and New Jersey ranges from less than $1 \%$ to $15 \%$ in any given bed. Thus, losses to fruit rot are currently in the range of $\$ 185$ to $\$ 10,950$ per ha.

\section{Cranberry Fruit Rot: A Case for Integrated Disease Management}

Since cranberry fruit rot is caused by numerous fungal species, control methods vary according to the species of fungi present, the prevalent type of fruit rot (field or storage), and how the fruit will be marketed. Currently, controlling this group of plant pathogens is most reliably achieved through timely fungicide applications. However, other methods, including various cultural practices, can reduce the primary inoculum load, and biocontrol regimes now under development also show promise.
Fungicide control. Fungicide applications initiated during bloom and completed shortly after fruit set are most effective in reducing infection by field-rotting fungi. Many of the newer classes of fungicides, such as sterol biosynthesis inhibitors, dicarboximides, and benzimidazoles, appear to be ineffective for fruit rot control $(15,19-21)$, possibly due to the specific modes of action or because effective use patterns have not been established. In fact, benomyl may actually increase the incidence of end rot caused by Fusicoccum putrefaciens (A. W. Stretch, unpublished data). The most effective fungicides continue to be broad-spectrum protectant-type biocides such as chlorothalonil, the EBDCs, and carbamates. With increased federal legislation (i.e., Food Quality Protection Act of 1996), a challenge for the future will be to identify and register new and effective fungicides or devise alternative practices for controlling cranberry fruit rot.

Cultural control. Several cultural practices are used that influence fruit rot incidence and severity. Application of late water is a practice that has been used in Massachusetts since the 1800s. The approach is to drain the winter floodwaters in early- to mid-March and then, 4 weeks later, re-flood and keep the beds flooded for 4 weeks. This treatment has been found to improve keeping quality of the crop, as well as to decrease the severity of some insect and weed problems. In addition, use of late water has been shown to reduce fruit rot incidence (68), thereby curtailing the need for fungicide applications for 2 years (1). Of eight pathogen species examined, two (Physalospora vaccinii and Phyllosticta elongata) increased and six
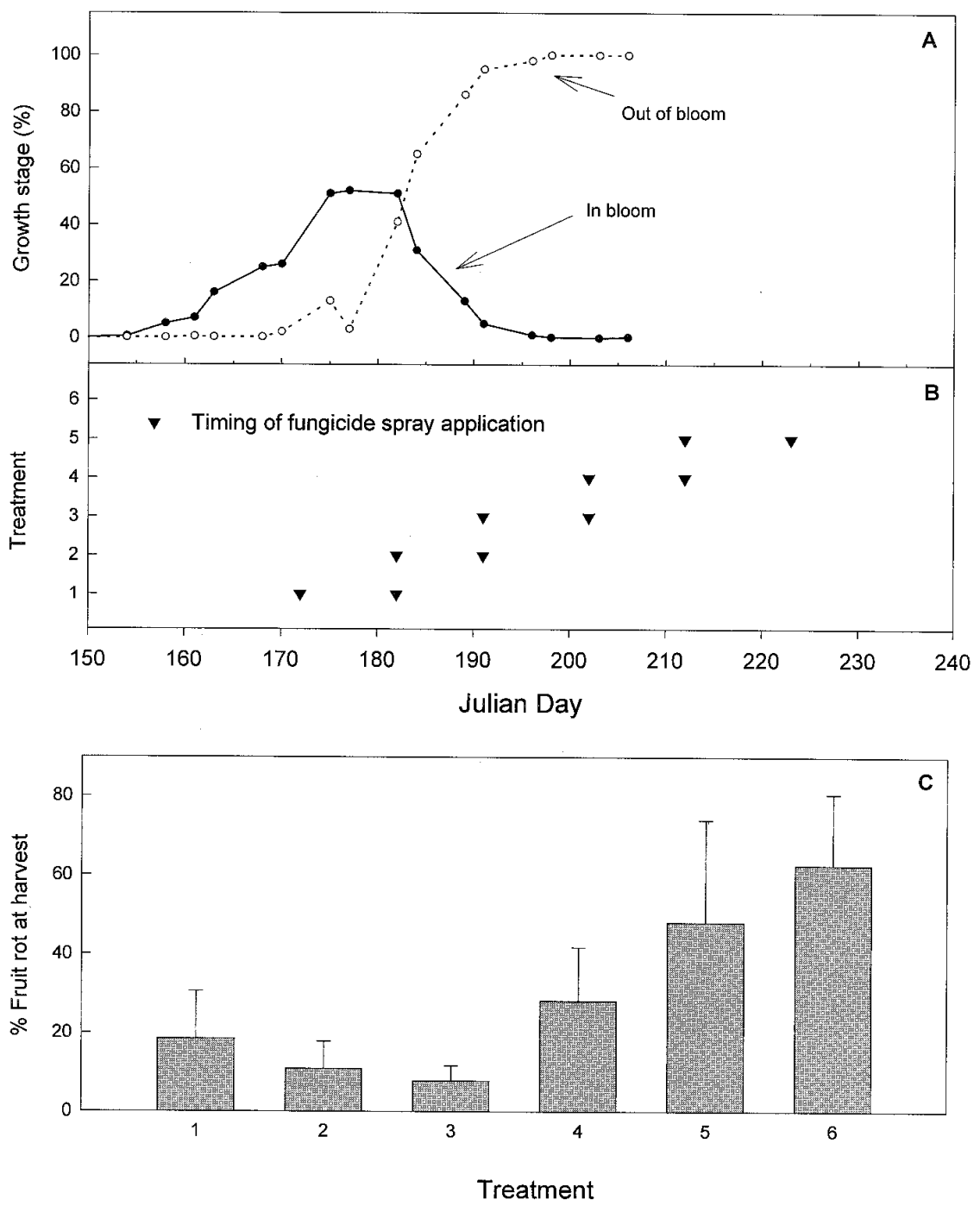

Fig. 11. Control of cranberry fruit rot with fungicide sprays applied at different times during the growing season. Results are from a field trial conducted at the Rutgers Blueberry and Cranberry Research and Extension Center in 1997. (A) Phenology of the cranberry crop. (B) Fungicide treatments (listed on the y-axis) were staggered at 10-day intervals. Treatments 1 to 5 each consisted of two sprays 10 days apart. Treatment 6 was an unsprayed control. (C) The level of fruit rot for each treatment at harvest. Harvest took place on day 268,46 days following the final fungicide application. 
(Allantophomopsis lycopodina, Coleophoma empetri, Glomerella cingulata, Fusicoccum putrefaciens, Phomopsis vaccinii, and Phyllosticta vaccinii) decreased in frequency in beds receiving late water $(\mathrm{F}$. L. Caruso, unpublished data). The mechanism by which applying late water affects fruit rot is unknown; however, one effect is to delay the onset of bloom by 10 to 14 days (68), resulting in a compression of the bloom period to about 20 days. Thus, avoidance of infections that lead to fruit rot may be a possible mechanism for disease reduction. Late water treatments have not been effective in managing fruit rot in New Jersey (A. W. Stretch, unpublished data).

Sanding is a practice where 2 to $5 \mathrm{~cm}$ of washed, screened sand is distributed evenly across the bed during the winter seasonusually when the beds are flooded. This is done either by using a sanding barge or by distributing the sand across the ice on frozen beds and allowing the sand to filter through the canopy during a thaw. The result of this practice is to improve vine vigor by burying runners and stimulating new root formation (58). It is suspected that this practice may reduce the amount of pathogen inoculum by burying the sources of inoculum. More work is needed to establish how the timing of sand applications can influence inoculum levels.

Drainage can have a significant effect on fruit rot incidence. First, poor drainage provides an ideal climate for fungal infection, resulting in an increase in rot levels. This has long been realized by Eastwood (28), who recommended that growers "raise the soil and bring it to the level of that part of the yard in which the cranberry does not rot." Second, high soil moisture and poor drainage are also conducive to increased root rot (caused by Phytophthora cinnamomi) incidence (23). The reduction in vine density caused by this pathogen can result in elevated fruit rot levels, possibly due to an increase in reflected heat. Thus, even in the unique environment of the cranberry bed, efficient drainage is critical to production of healthy fruit.
During the harvest of cranberries, numerous leaves and debris are also recovered from the beds. This material is sometimes separated from the fruit immediately and sometimes after the fruit is taken to a receiving station. The leaves, stems, and weeds recovered in this manner are placed in trash piles. Removal of these trash piles can aid in the reduction of inoculum load during the growing season (18). It is not clear how serious a factor trash piles are, since most of the pathogens appear to be dispersed over relatively short distances. Many growers remove trash piles from around cranberry beds because cranberry leaves are known to be potential reservoirs of fungal inoculum.

Cultural practices that reduce vine overgrowth, increase air circulation in the cranberry canopy, and enhance solar penetration will provide less favorable environments for fruit rot development. Pruning is one option commonly used for removing heavy vine growth. Pruning is normally done in the fall following harvest or during early spring before the vines resume growth. Dry harvesters (as opposed to water harvesters that pick fruit in flooded beds) also prune the vines as they pick fruit from dry beds. In addition, managing nitrogen levels to provide only the minimum necessary for berry production will limit vine overgrowth. Davenport (26) demonstrated that high levels of nitrogen would cause an increase in fruit rot levels. Practices that limit canopy overgrowth will also allow better penetration and coverage by fungicides and should promote more effective fruit rot control.

As discussed earlier, many of the important fruit diseases of cranberry survive in stems and leaves. Cuttings from established beds are often used to plant new beds. Thus, the pathogens are commonly introduced with the vines used to establish a bed. Crowley (24) suggested that some of the diseases and insects found in the $\mathrm{Pa}$ cific Northwest were imported with vines from eastern sources. Introduction of Phyllosticta vaccinii to Wisconsin occurred recently (42) and may have been avoided if planting stock were derived from tissue cultured plants. Other methods such as sterilization have not been sufficiently tested and are currently not an option. This type of sanitation could become more important as new regions adopt the practice of cranberry growing.

Resistance. Resistance to cranberry fruit rot pathogens is not well understood. The existing evidence indicates that resistance may not be specific to individual pathogen species. For example, Zuckerman (68) found no differences in the complement of fungi present on two different commercial cultivars in Massachusetts. Similarly, C. M. Stiles and P. V. Oudemans (unpublished) found no significant differences in the frequencies of seven species of fruitrotting fungi across 10 different cultivars. However, F. L. Caruso (unpublished data) found differences in the incidence of fruitrotting fungi across nine cultivars when sampling was performed several times during the growing season. In a 3-year study, 44 cultivars were compared for field and storage rot incidence (F. L. Caruso and J. S. Mika, unpublished data). The general finding indicated that the incidences of field and storage rots were not correlated and that high levels of each type could occur singly or together in the different cultivars evaluated. Differences noted in fruit rot incidence among cultivars are thought to reflect fruit rot resistance.

Biological control. The application of antagonistic microorganisms to protect susceptible host tissues has not been commercially utilized for cranberry fruit rot control. Stretch (56) found that several bacteria and some isolates of an Aureobasidium sp. gave protection from the black rot fungi Allantophomopsis spp. and Strasseria geniculata. The antagonists were applied following harvest and presumably colonized wounds formed during harvest that are also infection sites for the black rot fungi. Recently, research has been initiated to isolate bacterial antagonists using enrichment culture (40). This ap-

Table 1. Keeping quality predictive scheme developed by Franklin and Cross (24) for Massachusetts ${ }^{a}$

\begin{tabular}{|c|c|c|c|c|c|c|c|c|c|}
\hline \multirow[b]{2}{*}{ Time period } & \multicolumn{3}{|c|}{ Sunlight } & \multicolumn{3}{|c|}{ Air temperature ${ }^{\mathbf{b}}$} & \multicolumn{3}{|c|}{ Total rainfall } \\
\hline & Threshold & Under & Over & Threshold & Under & Over & Threshold & Under & Over \\
\hline Previous year & $2,558 \mathrm{~h}$ & 4 & 0 & $\mathrm{NA}^{\mathrm{c}}$ & $\ldots$ & $\ldots$ & NA & $\ldots$ & $\ldots$ \\
\hline February & $166 \mathrm{~h}$ & 1 & 0 & NA & $\ldots$ & $\ldots$ & NA & $\ldots$ & $\ldots$ \\
\hline March & $212 \mathrm{~h}$ & 0 & 2 & $1.1^{\circ} \mathrm{C}$ & 2 & 0 & $11.2 \mathrm{~cm}$ & 1 & 0 \\
\hline April & N/A & $\ldots$ & $\ldots$ & $6.7^{\circ} \mathrm{C}$ & 2 & 0 & $9.9 \mathrm{~cm}$ & 1 & 0 \\
\hline May & N/A & $\ldots$ & $\ldots$ & $13.3^{\circ} \mathrm{C}$ & 2 & 0 & $8.1 \mathrm{~cm}$ & 1 & 0 \\
\hline \multirow[t]{2}{*}{ June } & N/A & $\ldots$ & $\ldots$ & $17.8^{\circ} \mathrm{C}$ & 2 & 0 & $8.1 \mathrm{~cm}$ & 1 & 0 \\
\hline & & \multicolumn{2}{|c|}{$0-7$} & \multicolumn{3}{|c|}{$0-8$} & & \multicolumn{2}{|c|}{$0-4$} \\
\hline Keeping quality index & $=$ & \multicolumn{2}{|c|}{ Total sunlight values } & + & \multicolumn{2}{|c|}{ Total temperature values } & + & \multicolumn{2}{|c|}{ Total rainfall values } \\
\hline
\end{tabular}


proach has proven successful, but antagonists with strong effects in laboratory assays gave less encouraging results in the field (4). For antagonists to be successful commercially as biocontrol products, better microorganisms need to be found or improved formulations need to be developed.

\section{Future Prospects}

Cranberry fruit rot remains one of the most serious yield-limiting diseases affecting cranberry production in the East. The most effective fungicides currently registered for control are threatened with cancellation by new safety regulations. In New Jersey and Massachusetts, loss of registered fungicides without replacement could lead to nearly complete crop losses within 5 years. Development and implementation of an integrated approach using measures such as cultural practices, biological and nonchemical methods, and identification of new, environmentally benign fungicides is the immediate shortterm goal. Registration and use of systemic fungicides could ultimately lead to improved keeping quality of fruit produced in areas with high fruit rot pressure and to stabilization of keeping quality from year to year.

Cranberry fruit rot is often spoken of as a single entity. For example, fungicide labels read, "...for the control of cranberry fruit rot." Thus, in practice, we often treat the disease as a single entity when it is actually a disease complex. This approach works because broad-spectrum fungicides do not discriminate among the broad range of fungal species involved. In reality, cranberry fruit rot is caused by a diverse array of fungi with unique life cycles and different distributions. Management practices do sometimes focus on a single species. For example, Phomopsis vaccinii is the target of prebloom fungicide applications because it causes a recognizable vine disease in addition to a fruit rot. However, most current management methods focus on all fungal species at once. As disease management evolves toward using more environmentally benign fungicides, we may find that this situation will change. Many of the modern fungicides have a limited spectrum of activity, and consequently the numbers of fungal species controlled are fewer. Methods for rapid identification of causal organisms will provide essential information on species distributions. In addition, some fungal species may be more prone to developing resistance to newer fungicides. Research is needed to better understand pathogen life cycles. Development of cultural and biological controls targeting overwintering reservoirs or more precisely timed fungicide applications to correspond with fungal infection would be beneficial.

Host resistance has not been sufficiently examined, and many opportunities likely exist in the development of fruit rot resistant cultivars. Screening for host resistance poses a major problem, since one general resistance trait may not be equally effective against all fungal species. Thus, from a research standpoint, cranberry fruit rot must be viewed as several different diseases, and control methods targeted to each one should be viewed as components of fruit rot management.

\section{Acknowledgments}

We thank Amy Howell, Nicholi Vorsa, and two anonymous reviewers for many constructive criticisms. The section on life cycles was especially improved by one anonymous reviewer. We also thank Ocean Spray Cranberries, Inc., New Jersey Blueberry and Cranberry Research Council, Cape Cod Cranberry Growers Association, and USDACSREES for funding that supported directly or indirectly the research and writing of this manuscript.

\section{Literature Cited}

1. Averill, A. L., Sylvia, M. M., Kusek, C. C., and DeMoranville, C. J. 1997. Flooding in cranberry to minimize insecticide and fungicide inputs. Am. J. Alternative Agric. 12:50-54.

2. Avorn, J., Monane, M., Gurwitz, J., Glynn, R., Choodnovskiy, I., and Lipsitz, L. 1994. Reduction of bacteriuria and pyuria after ingestion of cranberry juice. J. Am. Med. Assoc. 271:751-754

3. Bain, H. F. 1926. Cranberry disease investigations on the Pacific coast. U.S. Dep. Agric. Dep. Bull. 1434.

4. Bansemir, I., MacDonald, G., Oudemans, P., and Kobayashi, D. 1996. Characterization of a bacterium that reduces infection of cranberry by Colletotrichum. Phytopathology 86:S119.

5. Batra, L. R. 1991. World Species of Monilinia (Fungi): Their Ecology, Biosystematics and Control. J. Cramer, Berlin.

6. Beckwith, C. S. 1932. Cranberry growing in New Jersey. N.J. Agric. Exp. Stn. Circ. 246.

7. Bergman, H. F. 1959. Oxygen deficiency as a cause of disease in plants. Bot. Rev. 25:417485 .

8. Bergman, H. F., and Wilcox, M. S. 1936. The distribution, cause and relative importance of cranberry fruit rots in Massachusetts in 1932, and 1933, and their control by spraying. Phytopathology 26:656-664.

9. Boone, D. M. 1982. End Rot of Cranberry A3196. University of Wisconsin Extension, Madison.

10. Boone, D. M. 1982. Hard Rot and Tip Blight of Cranberry A3194. University of Wisconsin Extension, Madison.

11. Boone, D. M. 1982. Viscid Rot and Upright Dieback of Cranberry A3195. University of Wisconsin Extension, Madison.

12. Boone, D. M., and Friend, R. J. 1986. Yellow Rot of Cranberry A3350. University of Wisconsin Extension, Madison.

13. Boone, D. M., and Schwarz, M. R. 1982. Black Rot of Cranberry A3197. University of Wisconsin Extension, Madison.

14. Boone, D. M., and Weidemann, G. J. 1986. Early Rot (Scald) of Cranberry and Blast of Blossoms and Young Fruit A3352. University of Wisconsin Extension, Madison.

15. Bristow, P. R., and Windom, G. E. 1990. Controlling field and post harvest fruit rots of cranberry with benomyl. Fungic. Nematicide Tests 45:65.

16. Brown, K. J. 1982. Physalospora vaccinii and its effect on cranberries in Wisconsin. M.S. thesis. University of Wisconsin, Madison.

17. Carris, L. M. 1990. Cranberry black rot fungi: Allantophomopsis cytisporea and Allanto- phomopsis lycopodina. Can. J. Bot. 68:22832291.

18. Caruso, F. L. 1991. Cranberry trash piles as a source of inoculum for fruit rot. Phytopathology 81:1163.

19. Caruso, F. L. 1988. Evaluation of fungicides for control of field rot of cranberries, 1987. Fungic. Nematicide Tests 43:83.

20. Caruso, F. L. 1990. Evaluation of fungicides for control of field and storage rot of cranberries, 1989. Fungic. Nematicide Tests 45:65.

21. Caruso, F. L. 1990. Evaluation of fungicides for control of field rot of cranberries. Fungic. Nematicide Tests 43:83.

22. Caruso, F. L., and Ramsdell, D. C., ed. 1995. Compendium of Blueberry and Cranberry Diseases. American Phytopathological Society, St. Paul, MN

23. Caruso, F. L., and Wilcox, W. F. 1990. Phytophthora cinnamomi as a cause of root rot and dieback of cranberry in Massachusetts. Plant Dis. 74:664-667.

24. Crowley, D. J. 1954. Cranberry growing in Washington. State College of Washington, Wash. Agric. Exp. Stn. Bull. 554.

25. Dale, A., Hansen, E. J., Yarborough, D. E., McNicol, R. J., Stang, E. J., Brennan, R., and Morris, J. R. 1994. Mechanical harvesting of berry crops. Hortic. Rev. 16:255-382.

26. Davenport, J. R. 1996. The effect of nitrogen fertilizer rates and timing on cranberry yield and fruit quality. J. Soc. Am. Hortic. Sci. 121:1089-1094.

27. DeMoranville, C., Sandler, H., and Bicki, T. 1996. Best management practices guide for Massachusetts cranberry production. University of Massachusetts, Cranberry Experiment Station.

28. Eastwood, B. 1866. A complete manual for the cultivation of the cranberry. Orange Judd $\&$ Co., New York.

29. Eaton, G. W., and Kyte, T. R. 1978. Yield component analysis in the cranberry. J. Am. Soc. Hortic. Sci. 103:578-583.

30. Eaton, G. W., and Macpherson, E. A. 1978 Morphological components of yield in cranberry. Hortic. Res. 17:73-82.

31. Eck, P. 1990. The American Cranberry. Rutgers University Press, New Brunswick, NJ.

32. Franklin, H. J., and Cross, C. E. 1948 Weather in relation to cranberry production and condition. University of Massachusetts. Bull. 450.

33. Friend, R. J., and Boone, D. M. 1968. Diaporthe vaccinii associated with dieback of cranberry in Wisconsin. Plant Dis. Rep. 52:341-344.

34. Goheen, A. C. 1951. Experiments with cranberry fruit rots. Annu. Meet. Am. Cranberry Growers' Assoc., 81st.

35. Hall, C. J. 1950. Mid-years of the 1850's finds growers troubled with insects and "the rot". Cranberries 15:3-17.

36. Halsted, B. D. 1889. Some fungus diseases of the cranberry. N.J. Agric. Coll. Exp. Stn. Bull. 64.

37. Hattendorf, M. J., and Davenport, J. R. 1996. Cranberry evapotranspiration. HortScience 31:334-337.

38. Jeffers, S. N. 1991. Seasonal incidence of fungi in symptomless cranberry leaves and fruit treated with fungicides during bloom. Phytopathology 81:636-644.

39. Jeffers, S. N., and Boone, D. M. 1994. Common names for diseases of cranberry. Common Names of Plant Diseases. Committee on Standardization of Common Names for Plant Diseases, American Phytopathological Society, St. Paul, MN

40. Kobayashi, D. Y., and El-Barrad, N. E. H 1996. Selection of bacterial antagonists using enrichment cultures for the control of summer patch disease in Kentucky bluegrass. Curr. Microbiol. 32:106-110.

41. Kobayashi, D. Y., Stretch, A. W., and Oude- 
mans, P. V. 1995. A bacterial leaf spot of highbush blueberry hardwood cuttings caused by Pseudomonas andropogonis. Plant Dis. 79:839-842.

42. McManus, P. S. 1998. First report of early rot of cranberry caused by Phyllosticta vaccinii in Wisconsin. Plant Dis. 82:350.

43. Roper, T. R., and Vorsa, N. 1997. Cranberry: Botany and horticulture. Hortic. Rev. 21:215249.

44. Schwarz, M. R., and Boone, D. M. 1983. Black rot of cranberry caused by Strasseria oxycocci. Plant Dis. 67:31-32.

45. Schwarz, M. R., and Boone, D. M. 1985. Effect of wounding on incidence of black rot of cranberry in Wisconsin. Plant Dis. 69:225227.

46. Shear, C. L. 1907. Cranberry Diseases. U.S. Dep. Agric. Bull. 110.

47. Shear, C. L., and Bain, H. F. 1929. Life history and pathological aspects of Godronia cassandrae Peck. (Fusicoccum putrefaciens Shear) on cranberry. Phytopathology 19:1017-1024

48. Shear, C. L., Stevens, N. E., and Bain, H. F. 1931. Fungous diseases of the cultivated cranberry. U.S. Dep. Agric. Tech. Bull. 258.

49. Stevens, N. E. 1929. A method of testing the keeping quality of certain small fruits. Phytopathology 19:593-596.

50. Stevens, N. E. 1932. Notable outbreaks of cranberry fruit rots in Massachusetts. Phyto- pathology 22:911-916

51. Stevens, N. E., and Bain, H. F. 1927. Storage rots of cranberries in the 1926 crop. Phytopathology 17:649-655.

52. Stevens, N. E., and Bain, H. F. 1928. Storage rots of cranberry in the 1927 crop. Phytopathology 18:809-814

53. Stevens, N. E., and Bain, H. F. 1929. Storage rots of cranberries in the 1928 crop. Phytopathology 19:1037-1039.

54. Stiles, C. M., and Oudemans, P. V. 1995. Glomerella cingulata and Colletotrichum spp. from cranberry in New Jersey. Phytopathology 85:1150.

55. Stiles, C. M., and Oudemans, P. V. 1997. Cranberry fruit rot pathogens isolated from various cranberry plant tissues over two growing seasons. Phytopathology 87:S94.

56. Stretch, A. W. 1989. Biological control of blueberry and cranberry fruit rots. Acta Hortic. 241:301-306.

57. Stretch, A. W., and Ceponis, M. J. 1983. Influence of water immersion time and storage period on black rot development in coldstored, water-harvested cranberries. Plant Dis. 67:21-23.

58. Strik, B. C., and Poole, A. P. 1995. Does sand application to soil surface benefit cranberry production? HortScience 30:47-49.

59. Uecker, F. A., and Caruso, F. L. 1988. Synchronoblastia crypta, a new coelomycetous pathogen of upright stems and fruits of cran- berry. Mycologia 80:344-347.

60. Vander Kloet, S. P. 1988. The Genus Vaccinium in North America. Agriculture Canada Publ. 1828

61. Vanderplank, J. E. 1963. Plant Diseases, Epidemics and Control. Academic Press, Inc., New York.

62. Varney, E. H. 1955. Fungicidal sprays for the control of fruit rots of Early Black cranberries, 1954. Proc. Annu. Meet. Am. Cranberry Growers Assoc., 85th.

63. Weidemann, G. J., and Boone, D. M. 1982 Taxonomy of Phyllosticta vaccinii (Coelomycetes) and a new name for the true anamorph of Botryosphaeria vaccinii (Dothideales, Dothioraseae). Mycologia 74:59-65.

64. Weidemann, G. J., and Boone, D. M. 1983. Incidence and pathogenicity of Phyllosticta vaccinii and Botryosphaeria vaccinii on cranberry. Plant Dis. 67:1090-1093.

65. Weidemann, G. J., and Boone, D. M. 1984 Development of latent infections on cranberry leaves inoculated with Botryosphaeria vaccinii. Phytopathology 74:1041-1043.

66. White, J. J. 1870. Cranberry Culture. Orange Judd \& Co., New York.

67. Wilcox, R. B. 1945. Control of cranberry fruit rots by spraying. U.S. Dep. Agric. Circ. 723

68. Zuckerman, B. M. 1958. Relative importance of cranberry fruit rot fungi during the storage and harvest seasons in Massachusetts, 19561957. Plant Dis. Rep. 42:1214-1221.

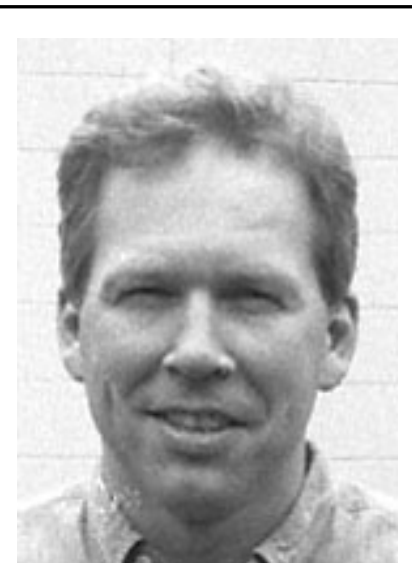

P. V. Oudemans

Dr. Oudemans is assistant professor of plant pathology and extension specialist for blueberry and cranberry diseases at Rutgers University Blueberry and Cranberry Research and Extension Center, Chatsworth, New Jersey. He earned his M.S. from the University of Guelph, Ontario, in 1986 and his Ph.D. from the University of California, Riverside, in 1990. Dr. Oudemans held postdoctoral positions at Duke University and the University of Kansas before coming to Rutgers in 1993. Previously, he worked with diseases of onions, avocados, and the white campion as well as pathogens such as Phytophthora and Ustilago. His current research is focused on the biology, etiology, and life cycles of cranberry and blueberry fungal pathogens. He is also working on a collaborative project to use remote sensing for detection and treatment of plant disease in a perennial crop.

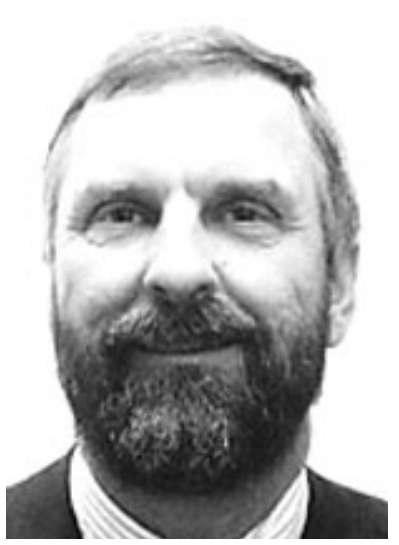

F. L. Caruso

Dr. Caruso is the extension associate professor of small fruit pathology at the University of Massachusetts Cranberry Experiment Station in East Wareham. $\mathrm{He}$ received a B.A. in biology at Gettysburg College in 1971, an M.S. in plant pathology at the University of Massachusetts in 1974, and a Ph.D. in plant pathology at the University of Kentucky in 1978. He was an assistant professor at the University of Maine prior to joining the staff at the Cranberry Station in June 1985. Dr. Caruso develops educational programs on cranberry disease management, runs a diagnostic clinic for small fruit diseases, and conducts research on fungal diseases of cranberry, including chemical, cultural, and biological control strategies. He is also an author of the Compendium of Blueberry and Cranberry Diseases published by the American Phytopathological Society in 1995.

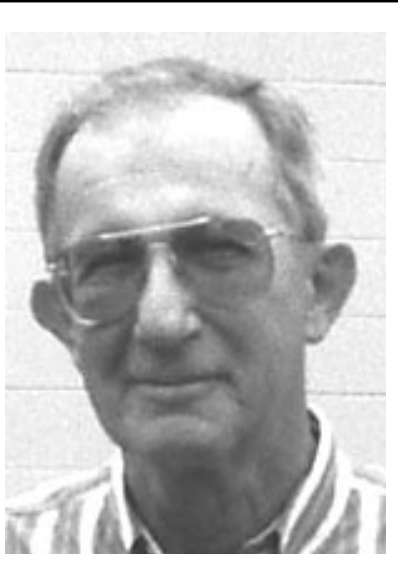

A. W. Stretch

Dr. Stretch is a research plant pathologist with the Agricultural Research Service of the United States Department of Agriculture. He received his B.S. in horticulture and his Ph.D. in plant pathology from Rutgers University in 1957 and 1962, respectively. Since 1962, he has been employed by USDA-ARS and stationed at Rutgers University in New Jersey to conduct disease research on blueberries and cranberries. His research activities have included fungicide management in the control of cranberry fruit rots, the use of fungicides in newly planted beds, impact of water harvesting on postharvest fruit quality, and novel ways to improve fruit quality for the fresh market. In addition, he has investigated fungal population progression in cranberry fruit over time as influenced by weather and fungicides. Currently, he is involved in testing late water treatments to improve fruit quality and reduce fungicide use under New Jersey conditions. 